\title{
Trichosporon xylopini sp. nov., a hemicellulose- degrading yeast isolated from the wood-inhabiting beetle Xylopinus saperdioides
}

Correspondence

Sung-Oui Suh

ssuh@atcc.org
Pushpa Gujjari, ${ }^{1}$ Sung-Oui Suh, ${ }^{1}$ Ching-Fu Lee ${ }^{2}$ and Jianlong J. Zhou ${ }^{1}$

${ }^{1}$ Mycology and Botany Program, American Type Culture Collection (ATCC), 10801 University Blvd, Manassas, VA 20110, USA

${ }^{2}$ Department of Applied Science, National Hsinchu University of Education, 521 Nanda Road, Hsinchu 30014, Taiwan

\begin{abstract}
Four arthroconidium-producing yeasts were isolated from the gut of wood-inhabiting tenebrionid and passalid beetles. The rRNA genes of these yeast strains were sequenced, compared and analysed. The sequence results and other taxonomic characterizations placed two of the strains into Trichosporon porosum, and the remaining strains, $\mathrm{EHO} 24^{\top}$ and $\mathrm{EH} 026$ which were isolated from Xylopinus saperdioides (Coleoptera: Tenebrionidae), into a novel species of the genus Trichosporon in the Porosum clade. Strain EN6S23 was independently isolated from forest soil in Taiwan and was identified as the same novel species based on identical sequences in the internal transcribed spacers (ITS) and the D1/D2 region of the LSU rRNA gene and similar physiological characteristics to those of strains $\mathrm{EHO} 24^{\top}$ and $\mathrm{EH} 026$. The three strains can assimilate cellulose and xylan as sole carbon source, and are clearly distinguished from their closest taxon,

T. porosum, by $14 \mathrm{nt}$ differences in the ITS and D1/D2 region. These strains did not reproduce sexually under the laboratory conditions tested. The novel species is proposed as Trichosporon xylopini sp. nov. (type strain EHO24 $4^{\top}=$ ATCC MYA $-4670^{\top}=$ CBS $11841^{\top}$ ).
\end{abstract}

\section{INTRODUCTION}

Yeasts in the genus Trichosporon are characterized morphologically by their production of arthroconidia with septate mycelia, and are often associated with soil and water although some species are commonly recognized as opportunistic pathogens (Guého et al., 1998). Some species of the genus Trichosporon are also known to be associated with insects. For example, strains of Trichosporon mycotoxinivorans and Trichosporon scarabaeorum were isolated from the gut of termites and scarab beetles, respectively (Middelhoven et al., 2004; Molnar et al., 2004). Trichosporon insectorum, a killer yeast isolated from scarab and passalid beetles in Panama, was also reported by Fuentefria et al. (2008). Members of the Trichosporon clade were identified as frequently collected yeasts from the digestive tract of beetles, many of which have not been described previously (Suh et al., 2005).

Interestingly, a few species of the genus Trichosporon, such as Trichosporon porosum, Trichosporon sporotrichoides and Trichosporon wieringae, are able to assimilate hemicelluloses and phenolic compounds which are mainly found in

Abbreviation: ITS, internal transcribed spacers.

The GenBank/EMBL/DDBJ accession numbers for the rRNA gene sequences from this study are FJ527221 and H0005752-HQ005762. plant tissues in nature (Middelhoven, 2004; Middelhoven et al., 2001). During a survey of microbial flora in the gut of wood-inhabiting insects, we found several basidiomycetous anamorphic yeasts which produce arthroconidia, and some of these yeasts were identified as an undescribed species of the genus Trichosporon. Here we describe the novel Trichosporon species isolated in this study and discuss its phylogeny and ecology.

\section{METHODS}

Yeast isolation and characterization. The wood-inhabiting beetles, Xylopinus saperdioides (Coleoptera: Tenebrionidae) and Odontotaenius disjunctus (Coleoptera: Passalidae), were collected from a rotten oak tree (Quercus sp.) on Bull Run Mountain (38 $49^{\prime} 42^{\prime \prime} \mathrm{N} 77^{\circ} 42^{\prime} 58^{\prime \prime} \mathrm{W}$ ) in Broad Run, Virginia, USA, on 12 June 2008. The methods for isolating yeasts from insects were described in detail in previously published papers (Suh \& Blackwell, 2004; Suh et al., 2004). Strain EN6S23 was isolated from a humus soil sample under bamboo forest in Meishan (23 $34^{\prime} 42^{\prime \prime} \mathrm{N} 120^{\circ} 38^{\prime} 57^{\prime \prime} \mathrm{E}$ ), Chiayi, Taiwan, on 3 November 2007 by the method previously described (Liu et al., 2008; Lee et al., 2009). The morphological observations and metabolic tests that constitute the yeast standard description were performed according to established methods (Yarrow, 1998; Barnett et al., 2000). Assimilation tests for carbon and nitrogen sources were done in liquid media. Starved inocula were used in the nitrogen and vitamin assimilation tests. The yeasts were observed individually or in mixed cultures for basidiospore formation 
on YM agar, $2 \%$ malt extract agar or cornmeal agar at $25{ }^{\circ} \mathrm{C}$ for up to 6 weeks (Yarrow, 1998). The degradation of cellulose and xylan was tested by the dye diffusion method using cellulose azure agar and RBB-xylan agar, respectively, as described by Pointing (1999). Assessment of killer activity was performed on modified YM agar (YM broth containing $15 \%$ glycerol, $2 \%$ agar, and $0.003 \%$ methylene blue) as described by Fuentefria et al. (2008). The test medium was buffered to $\mathrm{pH} 3.0-6.0$ at intervals of $0.5 \mathrm{pH}$ units with $100 \mathrm{mM}$ citrate-phosphate buffer. The following strains were used as sensitive strains for the test: Candida albicans ATCC 10231 and ATCC 14053; Candida lusitaniae ATCC 42720; Candida glabrata ATCC 15545; Candida parapsilosis ATCC $22019^{\mathrm{T}}$; Cryptococcus neoformans ATCC 14115, ATCC 18365 and ATCC 24064; and Filobasidium uniguttulatum ATCC 24227. T. insectorum ATCC MYA- $4361^{\mathrm{T}}$ was used as a positive control for killer activity (Fuentefria et al., 2008).

DNA sequencing and molecular phylogenetic analyses. The methods for nucleic acid extraction, PCR amplification and sequencing of rRNA genes were those discussed by Suh \& Zhou (2010). The complete sequences of the SSU rRNA gene, the internal transcribed spacers (ITS) including the 5.8S rRNA gene, and the D1/ D2 region of the LSU rRNA gene were sequenced with primers NS1, NS2, NS4, NS8, ITS1, ITS4, LR0R and LR3 using an ABI 3130xl automated DNA sequencer. Sequences from new isolates were compared to those of other yeasts in GenBank using the BLAST search program (Altschul et al., 1990). Selected DNA sequences were aligned with the multialignment program CLUSTAL X (Thompson et al., 1997) and adjusted visually. GenBank accession numbers for the DNA sequences generated in this study are: HQ005761/HQ005752/ HQ005757 (SSU rRNA gene/ITS including 5.8S rRNA gene/D1/D2 region of LSU rRNA gene) for strain $\mathrm{EH} 024^{\mathrm{T}}$; - $/ \mathrm{HQ} 005753 /$ HQ005758 for strain EH026; -/HQ005754/FJ527221 for strain EN6S23; -/HQ005756/HQ005760 for strain EH157; HQ005762/ HQ005755/HQ005759 for strain EH158 (-, sequence not determined). Maximum-parsimony analyses were performed using PAUP $4.0 \mathrm{~b} 10$ (Swofford, 2002). Heuristic tree searches were executed using the tree bisection-reconnection branch-swapping algorithm with random sequence analysis. Bootstrap values of the most parsimonious tree were obtained from 1000 replications. Base-pair differences were counted using BLAST2 sequences (Tatusova \& Madden, 1999) or from a manually aligned sequence database.

\section{RESULTS AND DISCUSSION}

\section{Characterization and molecular phylogeny of the novel species}

Among the yeasts isolated from wood-inhabiting insects and woody substrates, four strains were identified as species of the genus Trichosporon on the basis of DNA sequences and other taxonomic characteristics. The strains and sources are as follows: EH024 ${ }^{\mathrm{T}}\left(=\right.$ ATCC MYA $\left.-4670^{\mathrm{T}}\right)$ and EH026 (=ATCC MYA-4671) from the gut of Xylopinus saperdioides; EH157 and EH158 (=ATCC MYA-4673), from the gut of Odontotaenius disjunctus. Another strain, EN6S23 (=ATCC MYA-4672), which is taxonomically very similar to the above strains, was independently isolated from humus forest soil in Taiwan. Strains EH157 and EH158 were identified as Trichosporon porosum based on identical ITS and D1/D2 region sequences to those of the type strain CBS $2040^{\mathrm{T}}$ (Middelhoven et al., 2001). On the other hand, the remaining three strains were identified as a novel species of the genus Trichosporon which is phylogenetically close to T. porosum. Therefore, here we propose a novel species, Trichosporon xylopini sp. nov., to accommodate strains EH024 ${ }^{\mathrm{T}}, \mathrm{EH} 026$ and EN6S23.

The strains representing T. xylopini sp. nov. are identical to each other in the ITS and D1/D2 regions, but are clearly distinguished from their closest taxon T. porosum by $13 \mathrm{nt}$ substitutions and a gap in the regions. Interestingly, between the two taxa, more variability was shown in the $\mathrm{D} 1 / \mathrm{D} 2$ region (12 substitutions and 1 gap in $568 \mathrm{bp}$ ) than in the ITS region ( 1 substitution in $523 \mathrm{bp}$ ). This pattern of variability in the two regions has been shown frequently among the species in the order Trichosporonales, such as between Trichosporon laibachii and Trichosporon multisporum or between Trichosporon montevideense and Trichosporon domesticum (Scorzetti et al., 2002). There is no variation in the SSU rRNA gene between $T$. porosum and the novel species.

The genus Trichosporon could be divided into four major clades based on the sequence analyses of the D1/D2 region of the LSU rRNA gene and the ITS region (Fell et al., 2000; Scorzetti et al., 2002; Sugita et al., 1999), which were named Gracile, Porosum, Cutaneum and Ovoides by Middelhoven et al. (2004). An additional clade, Brassicae, was recognized by D1/D2 sequence analyses with expanded taxon sampling including several novel species isolated from bat guano samples (Sugita et al., 2005). These major clades of Trichosporon correspond to the serotypes associated with the occurrence of summer-type hypersensitivity pneumonitis as well as to the ubiquinone types (Sugita et al., 2001, 2005). A phylogenetic tree, reconstructed from the ITS and D1/D2 sequences (about $1.1 \mathrm{~kb}$ ) of 14 Trichosporon species including the novel species from this study, showed that T. xylopini sp. nov. is closely related to $T$. porosum in the Porosum clade of the genus Trichosporon (Fig. 1). T. xylopini sp. nov. made a clade with T. porosum with $100 \%$ bootstrap support, and the two species were grouped with other species in the Porosum clade, i.e. Trichosporon dehoogii, T. sporotrichoides, Trichosporon gamsii, T. wieringae, Trichosporon lignicola and strain JCM 12596 (known as 'Trichosporon coprophilum'). The Porosum clade was well supported by a high statistical value among the taxa compared in the tree (Fig. 1). Several phylogenetic studies with broader taxon samplings showed that some of the species in the genera Cryptococcus, Bullera and Cryptotrichosporon are closely related to the yeasts in the genus Trichosporon (e.g. Okoli et al., 2007; Middelhoven et al., 2004). For example, Cryptococcus curvatus, Cryptococcus humicola and a few other cryptococci were placed into clades with species of the genus Trichosporon in several phylogenetic trees from single or multigene sequences (e.g. Okoli et al., 2007). Taxonomic revision of those taxa may be necessary based on their phylogenetic positions within the order Trichosporonales.

In physiological tests, T. xylopini sp. nov. showed a similar pattern of results to T. porosum as the two species were able 


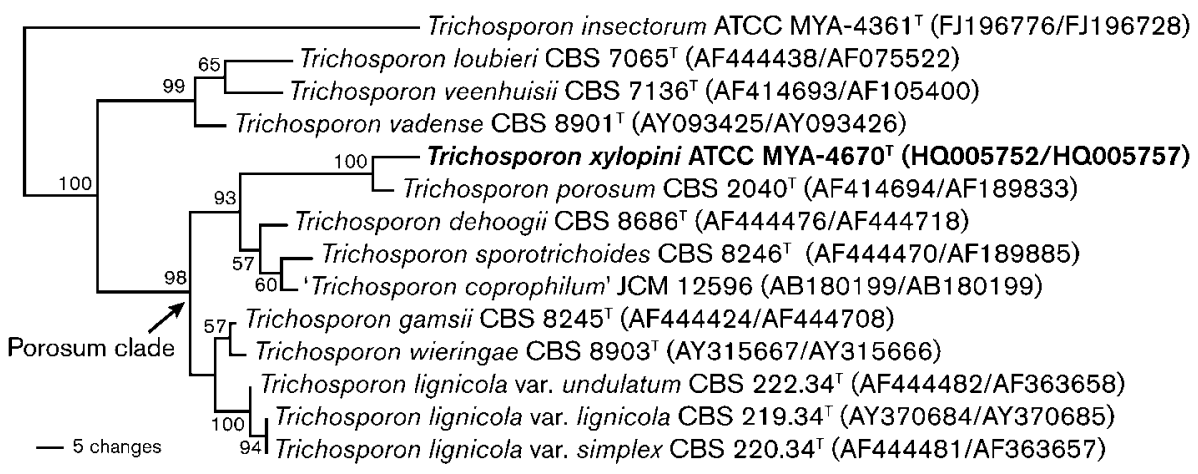

Fig. 1. A most-parsimonious tree obtained from the sequence data of the ITS including the 5.8S rRNA gene and the D1/D2 region of the LSU rRNA gene from Trichosporon xylopini sp. nov. and related taxa. Trichosporon insectorum was used as the outgroup taxon. GenBank accession numbers for ITS and D1/D2 sequences, respectively, are in parentheses. Tree length $=258$; consistency index $=0.8217$; retention index $=0.8796$; rescaled consistency index $=0.7228$. Numbers on branches indicate the percentages of bootstrap samplings derived from 1000 samples that supported the internal branches by $50 \%$ or higher. Bar, 5 changes per nucleotide position.

to utilize most of the carbon sources tested. However, the novel species differed from $T$. porosum by failure to assimilate quinic acid and sodium nitrite. Strains of $T$. xylopini sp. nov. are able to utilize xylan and cellulose for growth. Xylan is the principal hemicellulose in angiosperms and many other plants, and the ability to degrade xylan is also shown in other Trichosporon species of the Porosum clade, e.g. T. gamsii, T. lignicola, T. porosum, T. sporotrichoides and T. wieringae (Middelhoven, 2004).

Morphologically T. xylopini sp. nov. shares some characteristics with $T$. porosum, such as reproducing by budding more frequently than by generating arthroconidia under general culture conditions, and producing pseudomycelia in broth (Middelhoven et al., 2001). Sexual reproduction was not observed in any of the strains in the novel species individually or in mixed culture under the conditions tested for up to 6 weeks.

Interestingly, some strains of $T$. porosum are known to suppress growth of a variety of fungi with maximum antifungal activity at $\mathrm{pH} 3.5-4.0$ (Kulakovskaya et al., 2010). The suppression is due to secretion of a thermostable fungicidal agent which is similar to the antifungal cellobiose lipids produced by Cryptococcus humicola (Puchkov et al., 2002). Strains of T. xylopini sp. nov. and $T$. porosum isolated from this study were tested for growth suppression ability against the selected yeast strains listed earlier, but none of the strains showed any antifungal activity at the $\mathrm{pH}$ range tested $(\mathrm{pH} 3.0-6.0)$. Therefore, we conclude that the antifungal activity may be a strainvariable characteristic in $T$. porosum.

\section{Latin diagnosis of Trichosporon xylopini Suh, Lee, Gujjari \& Zhou sp. nov.}

Cultura in liquido 'YM' post 7 dies ad $25^{\circ} \mathrm{C}$, cellulae globosae, subglobosae et ellipsoideae $(3.0-5.0 \times 3.0-8.0 \mu \mathrm{m})$, singulae aut binae. Sedimentum formatur. Pseudohyphae fiunt. In agaro 'YM', post 7 dies ad $25^{\circ} \mathrm{C}$, cultura cremea, butyracea et margo fimbriata. Cultura in agaro farina Zeae maydis confecto post 11 dies ad $25{ }^{\circ} \mathrm{C}$ cremea. Arthroconidia, hyphae verae et pseudohyphae formantur. Saccharas non fermentantur. Assimilantur glucosum, galactosum, L-sorbosum, D-glucosaminum, D-ribosum, D-xylosum, L-arabinosum, Darabinosum, L-rhamnosum, sucrosum, maltosum, trehalosum, $\alpha$-methyl D-glucosidum, cellobiosum, salicinum, arbutinum, melibiosum, lactosum, raffinosum, melezitosum, amylum solubile, glycerolum, erythritolum, ribitolum, xylitolum, L-arabinitolum, D-glucitolum, D-mannitolum, galactitolum, inositolum, gluconolactonum, 2-keto D-gluconatum, Dgluconatum, D-glucuronatum, D-galacturonatum, DL-acidum lacticum, acidum succinicum, acidum citricum (lente, infirme), ethanolum et propane-1, 2-diolum. Non assimilantur inulinum, methanolum, butano-2, 3-diolum et acidum quinicum. Assimilantur ethylaminum (infirme), L-lysinum, cadaverinum et glucosaminum (lente). Non assimilantur kali nitratum, sodii nitritum, creatinum, creatininum, imidazolum et D-tryptophanum. Assimilantur cellulosum et xylanum. Amylum non formatur. Thiaminum externum ad crescentiam necessarium est. $30{ }^{\circ} \mathrm{C}$ crescit neque $37{ }^{\circ} \mathrm{C}$. In medio $0.01 \%$ cycloheximido addito crescit. Typus: EH024 ${ }^{\mathrm{T}}$ (ATCC MYA$\left.4670^{\mathrm{T}}=\mathrm{CBS} 11841^{\mathrm{T}}\right)$, designat stirpem typicum. Isolata a ile coleopterorum (Xylopinus saperdioides: Tenebrionidae), Broad Run, Virginia, USA, depositata in Collectione Culturarum American Type Culture Collection (ATCC), Manassas, Virginia, USA, et Centraalbureau voor Schimmelcultures (CBS), Utrecht, the Netherlands.

\section{Description of Trichosporon xylopini Suh, Lee, Gujjari \& Zhou sp. nov.}

Trichosporon xylopini (xy.lo.pi'ni. N.L. gen. n. xylopini of Xylopinus, referring to the genus name of the host beetle Xylopinus saperdioides for the type strain). 
After 7 days of growth in YM broth at $25{ }^{\circ} \mathrm{C}$, cells are globose to ellipsoidal $(3.0-5.0 \times 3.0-8.0 \mu \mathrm{m})$, and occur singly or in pairs (Fig. 2a) with sediment formed; budding yeast cells and pseudohyphae are present. The culture on YM agar after 7 days at $25{ }^{\circ} \mathrm{C}$ is cream coloured, butyrous and slightly wrinkled on top with filamentous edge. After 11 days of growth on Dalmau plate culture on cornmeal agar at $25^{\circ} \mathrm{C}$, true hyphae are present (Fig. 2b); fragmentation was observed only under the coverslip (Fig. 2b); aerobic growth is cream coloured with filamentous margin. Sexual reproduction was not observed from individual or mixed cultures of strains on YM agar, $2 \%$ malt extract agar or cornmeal agar at $25{ }^{\circ} \mathrm{C}$ for up to 6 weeks. Glucose, galactose, maltose, $\alpha$-methyl D-glucoside, sucrose, trehalose, melibiose, lactose, cellobiose, melezitose, raffinose, inulin, starch and D-xylose are not fermented. Glucose, galactose, L-sorbose, D-glucosamine, D-ribose, D-xylose, L-arabinose, D-arabinose, L-rhamnose, sucrose, maltose, trehalose, $\alpha$-methyl D-glucoside, cellobiose, salicin, arbutin, melibiose, lactose, raffinose, melezitose, soluble starch, glycerol, erythritol, ribitol, xylitol, L-arabinitol, D-glucitol, D-mannitol, galactitol, myo-inositol, Dglucono-1,5-lactone, 2-keto-D-gluconate, D-gluconate, D-glucuronate, D-galacturonic acid, DL-lactate, succinate, citrate (delayed, weak), ethanol and propane-1,2-diol are assimilated; inulin, methanol, butane-2,3-diol and quinic acid are not assimilated. Ethylamine (weak), L-lysine, cadaverine and D-glucosamine (delayed; as nitrogen source) are assimilated; potassium nitrate, sodium nitrite, creatine, creatinine, imidazole and D-tryptophan are not assimilated. Cellulose and xylan are assimilated. Thiamine is required for growth. Growth in $0.01 \%$ cycloheximide is positive. Growth on $1 \%$ acetic acid, $50 \%$ D-glucose, $60 \%$ D-glucose, $10 \% \mathrm{NaCl}$ and $16 \% \mathrm{NaCl}$ is negative. Growth at $30{ }^{\circ} \mathrm{C}$ is positive, while growth at $37{ }^{\circ} \mathrm{C}$ is negative. Starchlike compounds are not produced. Diazonium blue B reaction is positive. Urease activity is positive.

The type strain is EH024 $4^{\mathrm{T}}$ (ATCC MYA- $4670^{\mathrm{T}}=\mathrm{CBS}$ $\left.11841^{\mathrm{T}}\right)$, isolated from the gut of Xylopinus saperdioides (Coleoptera: Tenebrionidae) on rotten log (Quercus sp.), Bull Run Mountain, Broad Run, Virginia, USA.

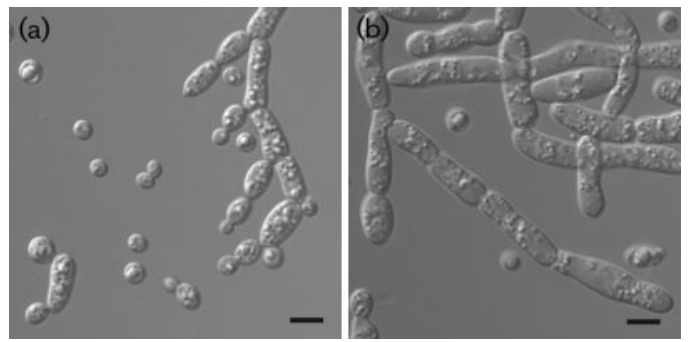

Fig. 2. Trichosporon xylopini sp. nov. strain $\mathrm{EH} 24^{\top}$. Budding yeast cells (a) after 7 days on YM agar at $25^{\circ} \mathrm{C}$, and arthroconidia (b) on Dalmau plate culture on cornmeal agar after 11 days at $25^{\circ} \mathrm{C}$. Bars, $5 \mu \mathrm{m}$.

\section{Ecology}

The darkling beetle Xylopinus saperdioides (Tenebrionidae) lives mainly on oak trees or under bark, although it is occasionally found on mushrooms such as Polyporus betulinus and Pleurotus ostreatus (Majka et al., 2008; Minch, 1952; Robinson, 1918; Cline \& Leschen, 2005). Two of the T. xylopini sp. nov. strains were isolated from this wood-inhabiting beetle found on a rotten oak tree, and the remaining strain was independently collected from humus soil. Previous studies showed that some of the gut yeasts were found not only from the digestive tract but also from the environment the host insects inhabited, such as frass of the host (e.g. Kodamaea laetipori; Suh \& Blackwell, 2005). Therefore, although T. xylopini sp. nov. strain EN6S23 was isolated from forest soil, we assume that its origin could be directly or indirectly related to insects, and the wood-inhabiting insects might play a major role in dispersing this yeast in nature.

It is interesting that strains of T. xylopini sp. nov. can degrade and utilize cellulose and xylan, which are the major components of plant tissues. As shown in previous studies on the gut micro-organisms of termites (Breznak \& Brune, 1994; Varma et al., 1994; Schäfer et al., 1996), this fact indicates that the yeast may help its host insect to digest the wood substrates taken as diet. Interestingly, the majority of Trichosporon species in the Porosum clade are known to utilize xylan, i.e. T. gamsii, T. lignicola, T. porosum, $T$. sporotrichoides, T. wieringa and the novel species T. xylopini (Middelhoven, 2004; this study), and their isolation sources are somewhat related to plant materials. For example, the strains of T. lignicola and the type strain of $T$. porosum were isolated from the wood pulp and exudate of yew tree, respectively (Fell \& Scorzetti, 2004; Middelhoven et al., 2001). Strains of T. gamsii, T. sporotrichoides and T. wieringae were found from forest soil such as moist humus (Guého et al., 1998; Middelhoven, 2004; Middelhoven et al., 2004). This circumstantial evidence indicates that those species of the genus Trichosporon may play a role in the decaying process of plants in the forest.

\section{ACKNOWLEDGEMENTS}

We thank Dr Joseph V. McHugh for identifying the beetle samples and Ms Erica L. Hart for assisting with beetle collection and yeast isolation. We are also grateful to Dr Brian Beck for his advice throughout this study, and to Ms Janice L. Houseknecht and ATCC internal review committee for critical reviewing of the manuscript. Dr Albert P. Torzilli allowed us to use his laboratory space in George Mason University for insect dissection. This work was supported in part by National Science Foundation Grant DBI-0548684 and ATCC Internship Program.

\section{REFERENCES}

Altschul, S. F., Gish, W., Miller, W., Myers, E. W. \& Lipman, D. J. (1990). Basic local alignment search tool. J Mol Biol 215, 403-410. 
Barnett, J. A., Payne, R. W. \& Yarrow, D. (2000). Yeasts: Characteristics and Identification, 3rd edn. Cambridge: Cambridge University Press.

Breznak, J. A. \& Brune, A. (1994). Role of microorganisms in the digestion of lignocellulose by termites. Annu Rev Entomol 39, 453-487.

Cline, A. R. \& Leschen, R. A. B. (2005). Coleoptera associated with the oyster mushroom, Pleurotus ostreatus Fries, in North America. Southeast Nat 4, 409-420.

Fell, J. W. \& Scorzetti, G. (2004). Reassignment of the basidiomycetous yeasts Trichosporon pullulans to Guehomyces pullulans gen. nov., comb. nov. and Hyalodendron lignicola to Trichosporon lignicola comb. nov. Int J Syst Evol Microbiol 54, 995-998.

Fell, J. W., Boekhout, T., Fonseca, A., Scorzetti, G. \& StatzellTallman, A. (2000). Biodiversity and systematics of basidiomycetous yeasts as determined by large-subunit rDNA D1/D2 domain sequence analysis. Int J Syst Evol Microbiol 50, 1351-1371.

Fuentefria, A. M., Suh, S.-O., Landell, M. F., Faganello, J., Schrank, A., Vainstein, M. H., Blackwell, M. \& Valente, P. (2008). Trichosporon insectorum sp. nov., a new anamorphic basidiomycetous killer yeast. Mycol Res 112, 93-99.

Guého, E., Smith, M. Th. \& de Hoog, G. S. (1998). Trichosporon Behrend. In The Yeasts, a Taxonomic Study, 4th edn, pp. 854-872. Edited by C. P. Kurtzman \& J. W. Fell. Amsterdam: Elsevier.

Kulakovskaya, T. V., Golubev, W. I., Tomashevskaya, M. A., Kulakovskaya, E. V., Shashkov, A. S., Grachev, A. A., Chizhov, A. S. \& Nifantiev, N. E. (2010). Production of antifungal cellobiose lipids by Trichosporon porosum. Mycopathologia 169, 117-123.

Lee, C. F., Yao, C. H., Liu, Y. R., Young, S. S. \& Chang, K. S. (2009), Kazachstania wufongensis sp. nov., an ascosporogenous yeast isolated from soil in Taiwan. Antonie van Leeuwenhoek 95, 335-341.

Liu, C. H., Young, S. S., Chang, T. C. \& Lee, C. F. (2008). Candida dajiaensis sp. nov., Candida yuanshanicus sp. nov., Candida jianshihensis sp. nov., and Candida sanyiensis sp. nov., four anamorphic, ascomycetous yeast species isolated from soil in Taiwan. FEMS Yeast Res 8, 815-822.

Majka, C. G., Bouchard, P. \& Bousquet, Y. (2008). Tenebrionidae (Coleoptera) of the Maritime Provinces of Canada. Can Entomol 140, 690-713.

Middelhoven, W. J. (2004). Trichosporon wieringae sp. nov., an anamorphic basidiomycetous yeast from soil, and assimilation of some phenolic compounds, polysaccharides and other non-conventional carbon sources by saprophytic Trichosporon species. Antonie van Leeuwenhoek 86, 329-337.

Middelhoven, W. J., Scorzetti, G. \& Fell, J. W. (2001). Trichosporon porosum comb. nov., an anamorphic basidiomycetous yeast inhabiting soil, related to the loubieri/laibachii group of species that assimilate hemicelluloses and phenolic compounds. FEMS Yeast Res 1, 15-22.

Middelhoven, W. J., Scorzetti, G. \& Fell, J. W. (2004). Systematics of the anamorphic basidiomycetous yeast genus Trichosporon Behrend with the description of five novel species: Trichosporon vadense, $T$. smithiae, T. dehoogii, T. scarabaeorum and T. gamsii. Int J Syst Evol Microbiol 54, 975-986.

Minch, E. L. (1952). Insect inhabitants of Polyporus betulinus. J NY Entomol Soc 60, 31-35.

Molnar, O., Schatzmayr, G., Fuchs, E. \& Prillinger, H. (2004). Trichosporon mycotoxinivorans sp. nov., a new yeast species useful in biological detoxification of various mycotoxins. Syst Appl Microbiol 27, 661-671.

Okoli, I., Oyeka, C. A., Kwon-Chung, K. J., Theelen, B., Robert, V., Groenewald, J. Z., McFadden, D. C., Casadevall, A. \& Boekhout, T. (2007). Cryptotrichosporon anacardii gen. nov., sp. nov., a new trichosporonoid capsulate basidiomycetous yeast from Nigeria that is able to form melanin on niger seed agar. FEMS Yeast Res 7, 339-350.

Pointing, S. B. (1999). Qualitative methods for the determination of lignocellulolytic enzyme production by tropical fungi. Fungal Divers 2, 17-33.

Puchkov, E. O., Zähringer, U., Lindner, B., Kulakovskaya, T. V., Seydel, U. \& Wiese, A. (2002). The mycocidal, membrane-active complex of Cryptococcus humicola is a new type of cellobiose lipid with detergent features. Biochim Biophys Acta 1558, 161-170.

Robinson, R. (1918). Beetles collected on a dead black oak in Virginia. J NY Entomol Soc 26, 30-33.

Schäfer, A., Konrad, R., Kuhnigk, T., Kämpfer, P., Hertel, H. \& König, H. (1996). Hemicellulose-degrading bacteria and yeasts from the termite gut. J Appl Bacteriol 80, 471-478.

Scorzetti, G., Fell, J. W., Fonseca, A. \& Statzell-Tallman, A. (2002). Systematics of basidiomycetous yeasts: a comparison of large subunit D1/D2 and internal transcribed spacer rDNA regions. FEMS Yeast Res 2, 495-517.

Sugita, T., Nishikawa, A., Ikeda, R. \& Shinoda, T. (1999). Identification of medically relevant Trichosporon species based on sequences of internal transcribed spacer regions and construction of a database for Trichosporon identification. J Clin Microbiol 37, 1985-1993.

Sugita, T., Takashima, M., Nakase, T., Ichikawa, T., Ikeda, R. \& Shinoda, T. (2001). Two new yeasts, Trichosporon debeurmannianum sp. nov. and Trichosporon dermatis sp. nov., transferred from the Cryptococcus humicola complex. Int J Syst Evol Microbiol 51, 1221-1228.

Sugita, T., Kikuchi, K., Makimura, K., Urata, K., Someya, T., Kamei, K., Niimi, M. \& Uehara, Y. (2005). Trichosporon species isolated from guano samples obtained from bat-inhabited caves in Japan. Appl Environ Microbiol 71, 7626-7629.

Suh, S.-O. \& Blackwell, M. (2004). Three new beetle-associated yeasts in the Pichia guilliermondii clade. FEMS Yeast Res 5, 87-95.

Suh, S.-O. \& Blackwell, M. (2005). Four new yeasts in the Candida mesenterica clade associated with basidiocarp-feeding beetles. Mycologia 97, 167-177.

Suh, S.-O. \& Zhou, J. J. (2010). Methylotrophic yeasts near Ogataea (Hansenula) polymorpha: a proposal of O. angusta comb. nov. and Candida parapolymorpha sp. nov. FEMS Yeast Res 10, 631-638.

Suh, S.-O., McHugh, J. V. \& Blackwell, M. (2004). Expansion of the Candida tanzawaensis yeast clade: 16 novel Candida species from basidiocarp-feeding beetles. Int J Syst Evol Microbiol 54, 2409-2429.

Suh, S.-O., McHugh, J. V., Pollock, D. D. \& Blackwell, M. (2005). The beetle gut: a hyperdiverse source of novel yeasts. Mycol Res 109, 261265.

Swofford, D. L. (2002). PAUP*: Phylogenetic analysis using parsimony (and other methods), version 4.0b10. Sunderland, MA: Sinauer Associates.

Tatusova, T. A. \& Madden, T. L. (1999). BLAST 2 sequences, a new tool for comparing protein and nucleotide sequences. FEMS Microbiol Lett 174, 247-250.

Thompson, J. D., Gibson, T. J., Plewniak, F., Jeanmougin, F. \& Higgins, D. G. (1997). The CLUSTAL_X windows interface: flexible strategies for multiple sequence alignment aided by quality analysis tools. Nucleic Acids Res 25, 4876-4882.

Varma, A., Kolli, B. K., Paul, J., Saxena, S. \& König, H. (1994). Lignocellulose degradation by microorganisms from termite hills and termite guts: A survey on the present state of art. FEMS Microbiol Rev 15, 9-28.

Yarrow, D. (1998). Methods for the isolation, maintenance and identification of yeasts. In The Yeasts, a Taxonomic Study, 4th edn, pp. 77-100. Edited by C. P. Kurtzman \& J. W. Fell. Amsterdam: Elsevier. 